Biblioteka Główna Uniwersytetu Ekonomicznego we Wrocławiu dawid.kosciewicz@ue.wroc.pl

\title{
ELEKTRONICZNE BAZY DANYCH W USLUGACH INFORMACYJNYCH BIBLIOTEKI AKADEMICKIEJ
}

\begin{abstract}
The aim of the paper is to discuss the challenges for providing effective scientific information in an economic library, in the context of use of electronic databases. The electronic databases subscribed by the Main Library of the Wrocław University of Economics are described, regarding the challenges for their use by the Library's users. The article is based on a subject literature from the field of science of librarian studies, as well as on the author's personal experience and observations. The paper ends with following conclusions: academic libraries have to conduct an effective information education of their users; increasing the information competences of users, regarding databases, should be a priority of librarians charged with scientific information; a beneficial form of enriching academic library's information resources is reaching for information sources of the European Union.
\end{abstract}

Słowa kluczowe: biblioteka akademicka, informacja naukowa, bazy danych.

\section{Wprowadzenie}

Biblioteka akademicka stanowi rdzeń uczelnianego systemu bibliotecznoinformacyjnego. W każdym układzie systemowym, lepsze są te rozwiązania, które efektywniej spełniają potrzeby jego użytkowników, a w przypadku bibliotek - gdy lepiej zaspokajają potrzeby informacyjne swoich czytelników. Zasoby informacyjne jakimi dysponuje biblioteka akademicka można uznać za główne kryterium analizy tego typu instytucji. Dotyczy to zwłaszcza oceny satysfakcji użytkowników i roli biblioteki we wspieraniu środowiska nauki. Zbiory tej instytucji, w odpowiedni sposób aktualizowane i udostępniane, są znaczącym aktywem dla potencjału naukowego uczelni wyższej ${ }^{1}$.

Podstawowym problemem zapewnienia kompletności zasobów informacyjnych są zazwyczaj kwestie finansowe. Uczelnie wyższe rzadko mogą

${ }^{1}$ M. Borowska, Efektywne zarzadzanie informacja petnotekstowa, [w:] Biblioteka Akademicka. Infrastruktura-Uczelnia-Otoczenie. Gliwice, 24-25 października 2013, Gliwice 2014, s. 89-94, http://delibra.bg.polsl.pl/Content/14692/Borowska_Marlena_tekst.pdf, [dostęp: 27.03.2017]. 
pochwalić się większymi środkami finansowymi, dlatego biblioteki akademickie często udostępniają wyłącznie bazy danych na licencji krajowej, biblioteki wyspecjalizowane mogą liczyć na wsparcie za pośrednictwem sieci bibliotek. Tak jest w przypadku Konsorcjum Bibliotek Kierunków Ekonomicznych ${ }^{2}$, wspólnymi siłami zapewniającego dostęp do najpopularniejszych baz ekonomicznych. Bez wsparcia innych instytucji zakup zasobów elektronicznych na potrzeby konkretnych naukowców lub katedr jest zwykle niemożliwy. Tym niemniej, jeśli kierownicy katedr skłonni są do finansowej partycypacji w kosztach, znacząco zwiększa to szansę na przekonanie władz wydziału lub uczelni do zakupu danej bazy.

\section{Rosnąca rola zasobów elektronicznych w zbiorach biblioteki akademickiej}

W udostępnianiu zasobów elektronicznych biblioteki akademickiej coraz powszechniej korzysta się z rozwoju technologii przetwarzania informacji w chmurze (cloud computing). Jest to korzystne ze względu na oszczędność własnych mocy obliczeniowych i bezpieczeństwo archiwizowanych danych. W bibliotekach akademickich często zajmują się tym zagadnieniem osoby bez teoretycznego przygotowania informatycznego, które chętnie korzystają z szerokiej definicji terminu ,chmury”. Dla bibliotekarza akademickiego chmura może byćs

- $\quad$ wirtualizacją sprzętu i oprogramowania, służącą uproszczeniu używanego sprzętu komputerowego i redukcji kadry informatycznej;

- $\quad$ strategią alokacji zasobów cyfrowych w celu ich lepszego zabezpieczenia i zwiększenia dostępności;

- implementacją zaawansowanych narzędzi indeksujących.

Jakkolwiek elektroniczne bazy danych subskrybowane przez biblioteki akademickie nie zawsze są oparte o technologię chmury, to z punktu widzenia samej biblioteki spełniają pewne kryteria tego rozwiązania. Subskrybowane bazy danych oraz zewnętrzne repozytoria nie obciążają mocy obliczeniowych serwerów bibliotecznych czy uczelnianych, a dostępność danych jest niezależna od wydajności serwerów samej biblioteki.

Wykorzystanie nowych technologii może poprawić konkurencyjność instytucji, jednak często pojawiają się także bariery związane z wdrażaniem zaawansowanych rozwiązań. Jednocześnie trudności związane z akceptacją

\footnotetext{
${ }^{2} K B K E$, http://kangur.uek.krakow.pl/biblioteka/konsorcjum/, [dostęp: 31.03.2017].

${ }^{3}$ A. Radwański, Chmury, chmury, chmury..., „Biuletyn EBIB” 2012, nr 8 (135), http:// open.ebib.pl/ojs/index.php/ebib/article/view/154, [dostęp: 31.03.2017].
} 
nowych technologii przez pracowników uczelni mogą prowadzić do strat finansowych i problemów zakłócających kulturę organizacyjną. Dotyczy to zwłaszcza użycia chmury zewnętrznej, która nie zapewnia odpowiedniego poziomu prywatności, bezpieczeństwa i kontroli ${ }^{4}$. Wydaje się, iż w przyszłości rozwiązania typu cloud computing mogą stać się ważnym komponentem usług w bibliotekarstwie akademickim, ponieważ oferują znaczącą poprawę efektywności systemów bibliotecznych. Nawet w mniej zaawansowanej technologicznie bibliotece, jej pracownik, o ile jest świadomy użyteczności nowych technologii informacyjnych, będzie zdolny do maksymalizacji użyteczności zasobów jakimi jego jednostka dysponuje. Jednocześnie bibliotekarze powinni przygotowywać się na pełne wykorzystanie technologii chmury, kiedy już będzie dostępna także w ich bibliotece ${ }^{5}$. Interesującym aspektem technologii chmury danych jest jej potencjalna użyteczność dla stworzenia w Polsce powszechnej usługi bibliotecznej, czyli chmury bibliotek ${ }^{6}$.

Niezależnie od szczegółowych rozwiązań, bazy danych są niezbędnym elementem współczesnych kolekcji bibliotecznych. Dotyczy to zwłaszcza akademickich bibliotek specjalistycznych, w tym także ekonomicznych. Nie oznacza to oczywiście, że bazy danych szybko zastąpią tradycyjne kolekcje. Na przeszkodzie stoją zarówno wymogi techniczne, niezbędne przy wykorzystaniu technologii chmury, jak i często umiarkowana popularność zasobów elektronicznych, dodatkowo ograniczona poziomem kompetencji informacyjnych użytkowników. Elektroniczne bazy danych oferujące książki naukowe jeszcze długo nie będą zawierać pełnych kolekcji tytułów będących w obszarze zainteresowania użytkowników biblioteki akademickiej (zwłaszcza w przypadku książek polskich wydawnictw), choć stopniowo ulega to zmianie. Wielu studentów wciąż niechętnie wybiera zasoby dostępne elektronicznie, sięgając po tradycyjne zbiory drukowane. Dotyczy to nawet czasopism, które w odróżnieniu od publikacji zwartych, coraz częściej są dostępne jako e-czasopisma. Co więcej, wydawnictwa stopniowo ustalają wersję elektroniczną swoich tytułów wydaniem podstawowym lub wręcz jedynym dostępnym. Wielu użytkowników przyjmuje zmiany z niepokojem, głównie z powodu braku odpowiednich kompetencji informacyjnych.

Ze względu na współczesne wyzwania jakie stoją przed bibliotekami akademickimi, związane z dążeniem do większej aktualności i różnorodności oraz

\footnotetext{
${ }^{4}$ W.W. Wu, L.W. Lan, Y.T. Lee, Factors hindering acceptance of using cloud services in University: a case study, „The Electronic Library”, 2013, vol. 31, issue 1, s. 84-98.

${ }^{5} \mathrm{~J}$. Mavedoza, The impact of cloud computing on the future of academic library practices and services, „New Library World”, 2013, vol. 114, issue 3/4, s. 132-141.

${ }^{6}$ A. Radwański, Chmura bibliotek, „Biuletyn EBIB” 2015, nr 3 (157/a), http:// open.ebib.pl/ojs/index.php/ebib/article/view/345, [dostęp: 31.03.2017].
} 
profesjonalizmu świadczenia informacji naukowej, konieczne są modyfikacje wielu aspektów ich działalności. Źródłem zmian w instytucjach mogą być: prawo, klienci, konkurencja, technologie i styl życia społeczeństwa ${ }^{7}$. Na podstawie tych przesłanek, biblioteki muszą dostosowywać swoje usługi informacyjne do zmieniającej się rzeczywistości (jak komputeryzacja), tak aby coraz skuteczniej realizować zadania stawiane im przez władze macierzystej uczelni. Bibliotekarze biorą aktywny udział w kształtowaniu i podnoszeniu kompetencji informacyjnych zarówno studentów, jak i pracowników naukowych. Z tego też względu, pracownicy bibliotek muszą nie tylko sami biegle posługiwać się nowoczesnymi narzędziami, ale też intensywnie promować ich wykorzystanie wśród swoich użytkowników. Dotyczy to zwłaszcza efektywnego wykorzystania baz danych, które są coraz ważniejszym źródłem informacji poszukiwanej w udostępnianych elektronicznie książkach i czasopismach, jak i danych czerpanych ze specjalistycznych zasobów dedykowanych konkretnej dyscyplinie nauki lub informacjom dotyczącym gospodarki i biznesu.

Jakkolwiek bazy specjalistyczne są najważniejszym zasobem elektronicznym dedykowanym studentom uczelni o sprofilowanej specjalności, nie mniejsze znaczenie odgrywają źródła o szerszym profilu. Dość powszechnie znane pełnotekstowe bazy danych (z wydawnictw takich jak: EBSCO, Science Direct, Emerald, Wiley czy Springer) wśród większości studentów cieszą się popularnością raczej niewielką i nie sposób właściwie tego zainteresowania efektywnie zwiększyć, zwłaszcza że są one przeznaczone dla bardziej doświadczonych badaczy. W odróżnieniu od doktorantów, którym bazy pełnotekstowe są niezbędne, studenci niższych stopni studiów z zagranicznych czasopism naukowych korzystają rzadko lub wcale. Do najpopularniejszych zasobów elektronicznych subskrybowanych przez Bibliotekę Główną Uniwersytetu Ekonomicznego we Wrocławiu (Biblioteka UEW) należy baza Ibuk Libra, która dobrze odpowiada potrzebom studentów. Na tle pozostałych zasobów pełnotekstowych jest to źródło o dość specyficznym doborze książek do kolekcji, zamiast wyników prac badawczych oferujące podręczniki i książki przydatne w toku studiów. Z powodu takiego charakteru dostępnych zasobów, Ibuk stanowi wygodne wprowadzenie studentów w system nauki oparty o pełnotekstowe bazy danych, a ponieważ umożliwia bibliotece dużą ingerencję w dobór tytułów, zapewnia użytkownikom dostęp do podręczników wymaganych przez wykładowców.

\footnotetext{
${ }^{7}$ M. Świrad, Przeobrażenia w bibliotece jako odpowiedź na zmieniające się potrzeby obecnych i przyszłych użytkowników, [w:] Dolnoślaskie Centrum Informacji Naukowej i Ekonomicznej-biblioteka otwarta, Wrocław 2011, s. 47-53.
} 


\section{Elektroniczne bazy danych $w$ informacji naukowej biblioteki ekonomicznej}

Bazy danych o profilu ekonomicznym i biznesowym mają nie tylko charakter agregatorów informacji. Są też często uniwersalnym, wielofunkcyjnym narzędziem, a korzystanie $\mathrm{z}$ nich wymaga pewnej wiedzy i umiejętności. Bardzo zaawansowane narzędzia ekonomiczne (jak baza Eikon wydawnictwa Thomson Reuters, czy baza Amadeus wydawnictwa Bureau Van Dijk), nie wymagają dużej mocy obliczeniowej komputera, zaś sama aplikacja zajmuje marginalne miejsce na dysku. Najpopularniejszymi bazami ekonomicznymi Biblioteki UEW, są EMIS (wydawnictwa Euromoney Polska) oraz Passport (wydawnictwa Euromonitor International), stąd w tabeli 1 na potrzeby artykułu zostały przedstawione dane dotyczące zagadnienia spadającego wykorzystania tych źródeł przez użytkowników bibliotek ekonomicznych.

Wyraźnie widać, że za wyjątkiem bardzo wysokiego wzrostu wykorzystania bazy EMIS na Uniwersytecie Ekonomicznym w Krakowie oraz niewielkiego wzrostu w Szkole Głównej Handlowej, zarówno EMIS jak i Passport w 2016 r. wykazują malejącą popularność wśród użytkowników w stosunku do wykorzystania w 2015 r. Jest prawdopodobne, że głównym powodem tego jest brak umiejętności obsługi tych zasobów przez studentów. Na bibliotekarzach spoczywa zadanie podnoszenia kompetencji informacyjnych w zakresie obsługi baz danych, ale bez realnej potrzeby wykorzystania danego zasobu, student raczej z niego nie skorzysta. Widać to na przykładzie uczestników obowiązkowych zajęć bibliotecznych, prowadzonych zwykle dla studentów pierwszego roku. Mimo tego, iż prezentowane im wówczas zasoby elektroniczne traktują z pewnym zaciekawieniem, to zazwyczaj nie widzą w nich użytecznego dla siebie narzędzia. Dopiero potem, na kolejnych latach studiów, a zwłaszcza w czasie pisania swojej pracy dyplomowej lub magisterskiej, zaczynają rozumieć, jak ważne i użyteczne są subskrybowane przez bibliotekę zasoby elektroniczne. W przypadku bibliotek specjalistycznych dużą rolę odgrywa łączenie popularyzacji informacji o zasobach (także w ramach obowiązkowego przysposobienia bibliotecznego), z włączaniem tych narzędzi w program zajęć dydaktycznych. Ciężar tego zadania leży po stronie pracowników dydaktycznych danej uczelni.

Na przykładzie Biblioteki UEW można wskazać kluczową rolę nauczycieli akademickich w kształtowaniu odpowiednich nawyków w efektywnym wykorzystaniu baz danych. W 2015 r. studenci drugiego roku kierunku Finanse i Rachunkowość byli zobowiązani do przygotowania projektu semestralnego w oparciu o dane ze sprawozdań finansowych spółek, pobranych z EMIS. W okresie kilku miesięcy zainteresowanie bazą znacząco wzrosło, 
亭

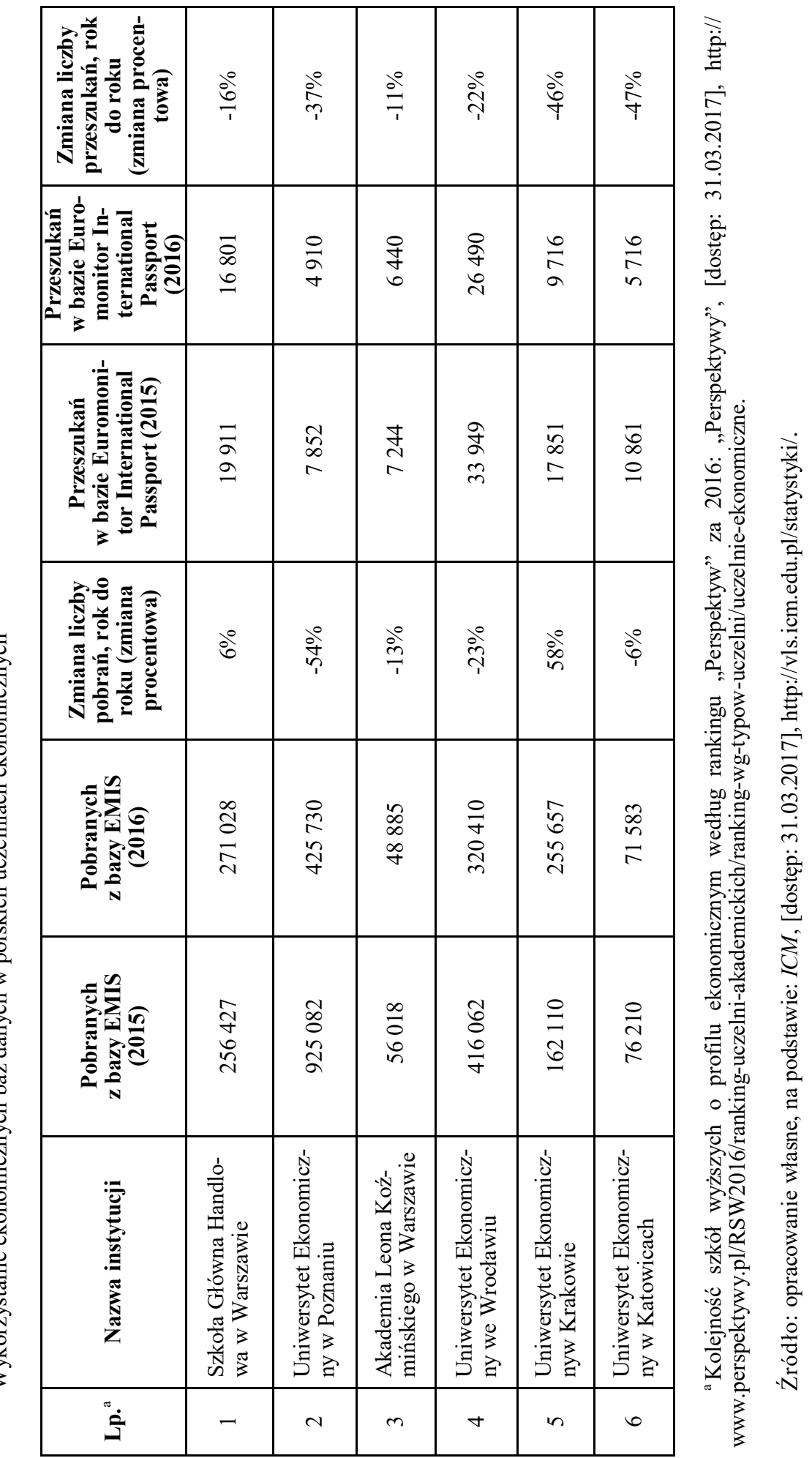


a bibliotekarze chętnie służyli zainteresowanym studentom dodatkowym przeszkoleniem i wskazówkami (w celu odświeżenia informacji z obowiązkowych kursów bibliotecznych, w trakcie których baza była prezentowana w poprzednim roku akademickim). W kolejnych latach takie zainteresowanie już nie było widoczne, choć trzeba też przyznać, że w podobny sposób tymczasowo wzrosło zainteresowanie bazami Amadeus oraz Thomson Reuters Eikon, kiedy inni nauczyciele akademiccy również zobowiązywali studentów do sporządzenia pracy zaliczeniowej w oparciu o wskazane źródła. Rezygnacja prowadzącego dany przedmiot $\mathrm{z}$ wykorzystania baz danych $\mathrm{w}$ dydaktyce, może skutkować spadkiem zainteresowania studentów skomplikowanymi zasobami elektronicznymi. Rolą bibliotekarzy powinno więc być promowanie tych zasobów, zarówno wśród studentów (jako narzędzi efektywnego pisania prac zaliczeniowych), jak i pracowników naukowych (jako wartościowego uzupełnienia ich programu dydaktycznego). Skuteczną metodą promocji zasobów jest oferowanie pracownikom naukowym wizyty bibliotekarza na zajęciach, zwłaszcza laboratoryjnych, w celu prezentacji wybranych baz danych. Jest to forma bezpośredniej i korzystnej dla obu stron współpracy na linii biblioteka akademicka - pracownicy naukowo-dydaktyczni macierzystej uczelni.

W odróżnieniu od zazwyczaj prostych w obsłudze baz pełnotekstowych, umożliwiających użytkownikom dostęp do książek i czasopism naukowych, bazy ekonomiczne dedykowane gromadzeniu i udostępnianiu użytkownikom danych faktograficznych dotyczących spółek i branż, nie zawsze są intuicyjne w obsłudze. Brak umiejętności, połączony z brakiem chęci ich podniesienia, obniża szansę na zainteresowanie się konkretnym źródłem w przyszłości. Wynika to niewątpliwie ze strachu przed złożonością obsługi bazy danych, jak również przyzwyczajenia studentów do korzystania z popularnych wyszukiwarek internetowych, które często oferują wyniki mniej relewantne i kompletne, charakteryzują się jednak banalnym interfejsem i bardzo zaawansowanym algorytmem wyszukiwania. Jednocześnie algorytmy współczesnych wyszukiwarek internetowych większą wagę przywiązują do budowy strony niż rzeczywistej wartości informacji. Natomiast bazy danych są narzędziem wymagającym od użytkowników większych kompetencji informacyjnych, ale zarazem dużo precyzyjniejszym. Dlatego zadaniem bibliotekarzy akademickich powinno więc być promowanie tego typu zasobów wśród ich potencjalnych użytkowników.

Bibliotekarz jako zarządca dostępnej informacji elektronicznej, stwarzający warunki do kształcenia z wykorzystaniem zasobów cyfrowych ${ }^{8}$, sam musi aktywnie działać na rzecz podnoszenia kompetencji informacyjnych studentów

${ }^{8}$ B. Chrapczyńska, Nowoczesne ustugi informacyjne kluczem do sukcesu użytkowników. Stan obecny i perspektywy, [w:] Biblioteka - klucz do sukcesu użytkowników (ePublikacje 
i pracowników naukowych uczelni. W ramach edukacji informacyjnej Biblioteki UEW prowadzone są zajęcia z Przysposobienia Bibliotecznego, Elektronicznych Źródeł Informacji Naukowej, anglojęzyczne Library Information Systems oraz rozbudowany kurs e-learningowy 9 . W strukturze Biblioteki UEW funkcjonuje oddział informacji naukowej. Pracownicy oddziału nie tylko świadczą usługi z zakresu bibliograficznej informacji naukowej, ale także prowadzą na życzenie użytkowników indywidualne szkolenia $\mathrm{z}$ obsługi baz, szczególnie skomplikowanych w obsłudze baz ekonomicznych. Warto podkreślić, że włączanie bibliotekarzy do ogólnouczelnianego procesu dydaktycznego podnosi rangę biblioteki oraz pomaga w lepszym wykorzystaniu jej zasobów ${ }^{10}$.

\section{Zasoby informacyjne Unii Europejskiej jako uzupełnienie zbiorów biblioteki}

Na podstawie doświadczeń Biblioteki UEW, za bardzo korzystny element wzbogacania potencjalnych źródeł informacji ekonomicznej i naukowej można uznać dołączenie do sieci Centrów Dokumentacji Europejskiej (CDE). Są to punkty informacyjne Komisji Europejskiej, które funkcjonują w ramach powiązań umożliwiających przekierowywanie zapytań użytkowników biblioteki do centrów z innych akredytowanych ośrodków. Choć służy to głównie poszukiwaniu rzadkich publikacji naukowych na temat integracji europejskiej, jest także często wykorzystywane przy poszukiwaniu aktów prawnych. CDE może być również użyteczne na uczelniach ekonomicznych za sprawą przekazywania know-how odnośnie pozyskiwania informacji statystycznej. Dotyczy to zwłaszcza Eurostatu, którego baza danych ma opinię skomplikowanej w obsłudze oraz trudnej w interpretacji, ze względu na nie zawsze zrozumiałą metodologię badawczą.

Jedną z form poprawy dostępności i aktualności źródeł informacji, użytecznych zwłaszcza w badaniach na podstawie danych statystycznych, jest uzyskanie dostępu do mikrodanych Eurostatu. Mikrodane to dane obserwacyjne dotyczące jednostki statystycznej - czyli obywatela, gospodarstwa domowego lub przedsiębiorstwa ${ }^{11}$. Mikrodane są dostarczane badaczom tylko po spełnieniu przez instytucję zobowiązaną do ich udostępniania surowych kryteriów

Instytutu Informacji Naukowej i Bibliotekoznawstwa, nr 5), Kraków 2008, s. 142-149, [dostęp: 27.03.2017], http://skryba.inib.uj.edu.pl/wydawnictwa/e05/chrapczynska-n.pdf.

${ }^{9}$ Biblioteka UEW, http://www.bg.ue.wroc.pl/index.php/zajecia-dydaktyczne, [dostęp: 31.03.2017].

${ }^{10}$ B. Chrapczyńska, M. Świrad, Edukacja informacyjna $w$ bibliotece akademickiej, [w:] Biblioteka na miarę: przestrzeń, zasoby, ustugi, Wrocław 2016, s. 153-168.

${ }^{11}$ Eurostat, http://ec.europa.eu/eurostat/web/microdata, [dostęp: 31.03.2017]. 
odpowiedniej anonimizacji danych, uniemożliwiającej identyfikację jednostek statystycznych. Wykorzystanie mikrodanych jako źródła do badań jest sposobem na prowadzenie bardziej pogłębionych analiz społeczno-ekonomicznych, niż umożliwiłoby to wykorzystanie tylko publicznie dostępnych źródeł, oferowanych przez instytucje statystyczne zarówno na poziomie krajowym, jak i międzynarodowym. Biblioteka UEW zachęcona zainteresowaniem użytkowników (głównie doktorantów i pracowników naukowych Uczelni), podjęła starania o uzyskanie akredytacji Eurostatu, która umożliwia pracownikom i doktorantom zgłaszanie projektów badawczych wykorzystujących poufne dane statystyczne. Procedura uzyskania akredytacji była skomplikowana i wymagała ścisłej współpracy różnych działów Uczelni, jednak dzięki jej pozytywnemu przejściu możliwe stało się udostępnianie za pośrednictwem Biblioteki UEW danych statystycznych, których dostępność jest realnym wsparciem dla potencjału badań naukowych.

\section{Zakończenie}

Zasoby elektroniczne bibliotek akademickich stanowią ważną część ich kolekcji i odgrywają rosnącą rolę w świadczeniu informacji naukowej. Nie ulega wątpliwości fakt, iż te instytucje stoją przed koniecznością rozbudowy swoich zasobów elektronicznych, w niezbyt odległej przyszłości także w oparciu o coraz powszechniejszą technologię cloud computing. Niezależnie do rozwiązań technicznych, bazy danych należą do podstawowych instrumentów informacji naukowej biblioteki akademickiej, jednocześnie są one zarówno narzędziem, jak i przedmiotem efektywnej edukacji bibliotecznej. W związku z tym podnoszenie kompetencji informacyjnych użytkowników, zwłaszcza w kontekście użycia baz danych, powinno być priorytetem bibliotekarzy zajmujących się informacją naukową. W artykule zwrócono uwagę na trudności w popularyzacji wykorzystania tego typu zasobów przez użytkowników. Problemy dotyczą zwłaszcza studentów, szczególnie niższych poziomów studiów, którzy nie są zobowiązani do korzystania ze źródeł specjalistycznych. Bibliotekarze powinni wykorzystywać wszystkie okazje do promocji zasobów elektronicznych. W przypadku studentów powinny być to bardzo proste w nawigacji, a jednocześnie bardzo użyteczne bazy pełnotekstowe, takie jak Ibuk Libra; w przypadku doktorantów należy promować bazy specjalistyczne.

Szkolenie użytkowników pod kątem ich potrzeb, rozwiązywanie problemów, poznawanie popularnych potrzeb informacyjnych - to elementy podnoszące także kompetencje informacyjne bibliotekarzy. Dotyczy to w szczególności poszukiwania informacji za pomocą baz danych, zasobu informacyjnego którego znaczenie z roku na rok będzie rosło. Pracownicy bibliotek muszą 
z dużym zainteresowaniem podejść do kwestii intensywnego wykorzystania baz danych w informacji naukowej i edukacji informacyjnej. Samo udostępnianie baz danych nie jest wystarczające, zwłaszcza w przypadku trudniejszych w obsłudze baz specjalistycznych. Dlatego ważne jest, aby osoby zajmujące się informacją naukową nieustannie podnosiły także własne kompetencje i śledziły zmiany w interfejsie baz oraz rodzaju dostępnych tam danych. Biblioteka powinna wzbogacać swoje zasoby informacyjne o rozwiązania, które nie wymagają poniesienia dużych kosztów, na przykład pozyskanie dostępu do statystycznych źródeł europejskich. Istotne jest w związku z tym, żeby bibliotekarze permanentnie rozważali wzbogacenie zasobów o źródła, które nawet jeśli mogą wydawać się dość niszowe, będą stanowić wartościowe uzupełnienie oferty biblioteki.

\section{Bibliografia}

Borowska M., Efektywne zarzadzanie informacja petnotekstowa, [w:] Biblioteka Akademicka. Infrastruktura-Uczelnia-Otoczenie. Gliwice, 24-25 października 2013, Gliwice 2014, s. 89-94, http://delibra.bg.polsl.pl/Content/14692/Borowska_Mar lena_tekst.pdf, [dostęp: 22.06.2018].

Chrapczyńska B., Nowoczesne ustugi informacyjne kluczem do sukcesu użytkowników. Stan obecny i perspektywy, [w:] Biblioteka - klucz do sukcesu użytkowników (ePublikacje Instytutu Informacji Naukowej i Bibliotekoznawstwa, $n r$ 5), Kraków 2008, s. 142-149, http://skryba.inib.uj.edu.pl/wydawnictwa/e05/chrap czynska-n.pdf, [dostęp: 22.06.2018].

Edukacja informacyjna $w$ bibliotece akademickiej, [w:] Biblioteka na miarę: przestrzeń, zasoby, ustugi, Wrocław 2016, s. 153-168.

Eurostat, [dostęp: 22.06.2018], http://ec.europa.eu/eurostat/web/microdata.

ICM, [dostęp: 22.06.2018], http://vls.icm.edu.pl/statystyki/.

KBKE, [dostęp: 22.06.2018], http://kangur.uek.krakow.pl/biblioteka/konsorcjum/.

Mavedoza J., The impact of cloud computing on the future of academic library practices and services, „New Library World”, 2013, vol. 114, issue 3/4, s. 132-141.

„Perspektywy”, http://www.perspektywy.pl/RSW2016/ranking-uczelni-akademickich/ ranking-wg-typow-uczelni/uczelnie-ekonomiczne, [dostęp: 22.06.2018].

Radwański A., Chmura bibliotek, „Biuletyn EBIB” 2015, nr 3 (157/a), http:// open.ebib.pl/ojs/index.php/ebib/article/view/345, [dostęp: 22.06.2018].

Radwański A., Chmury, chmury, chmury..., „Biuletyn EBIB” 2012, nr 8 (135), [dostęp: 22.06.2018], http://open.ebib.pl/ojs/index.php/ebib/article/view/154.

Świrad M., Przeobrażenia w bibliotece jako odpowiedź na zmieniająe się potrzeby obecnych i przyszlych użytkowników, [w:] Dolnoślaskie Centrum Informacji Naukowej i Ekonomicznej - biblioteka otwarta, Wrocław 2011, s. 47-53.

Wu W.W., Lan L.W., Lee Y.T., Factors hindering acceptance of using cloud services in University: a case study, „The Electronic Library”, 2013, vol. 31, issue 1, s. 84-98. 